\title{
Distribution and diet of Cyclothone microdon (Gonostomatidae) in a submarine canyon
}

\author{
S.E. THOMPSON AND T.J. KENCHINGTON \\ Department of Fisheries \& Oceans, Maritimes Region, Ocean Ecosystem Sciences Division, Bedford Institute of Oceanography, PO \\ Box 1006, Dartmouth, Nova Scotia B2Y 4A2, Canada
}

\begin{abstract}
The primarily bathypelagic gonostomatid Cyclothone microdon, amongst the most abundant of all vertebrates, remains poorly known. We describe its diet in The Gully, a very large submarine canyon off Nova Scotia, Canada, based on the stomach contents of specimens caught by midwater trawl. In The Gully, C. microdon had a shallower distribution than in open ocean and primarily fed at mesopelagic depths. Most of its diet comprised vertically migrant calanoid copepods, while its secondary prey was conchoeciinid ostracods. Both were typical of the food eaten in other regions by its mesopelagic congeners and were consistent with the results of the only previous dietary study of C. microdon.
\end{abstract}

Keywords: Cyclothone microdon, diet, depth distribution, submarine canyon

Submitted 27 May 2015; accepted 3 June 2016; first published online 8 July 2016

\section{INTRODUCTION}

Following Marshall (1954), Cyclothone (Gonostomatidae, Stomiiformes) is often claimed to be the most abundant of all vertebrate genera. Most of its 13 species have depth ranges centred in the mesopelagic zone, where what little they eat comprises vertically migrant calanoid copepods, with lesser quantities of ostracods, plus trace amounts of other mesozooplankton (De Witt \& Cailliett, 1972; Gorelova, 1980; Maynard, 1982; Mauchline \& Gordon, 1983; Roe \& Badcock, 1984; Gordon et al., 1985; Palma, 1990; Yoon et al., 2007; McClain-Counts, 2010). In contrast, the circumglobal Cyclothone microdon (Günther 1878), amongst the most abundant of all fish species, is largely bathypelagic, being found primarily at 500-2700 m depth (Badcock, 1984). Since Cyclothone spp. show little evidence of vertical migration, C. microdon might be expected to sustain itself on the scarce resources available below the depths reached by mesopelagic diel migrants. To date, however, only Mauchline \& Gordon (1983) have provided substantial information on the diet of that species, which they derived from 68 stomachs containing identifiable prey, taken from specimens caught in the Rockall Trough at unreported depths. Those individuals had consumed similar prey to that of their shallower-dwelling congeners.

From 2007 to 2010, four midwater-trawl surveys were conducted in The Gully (Figure 1), a very large submarine canyon incised into the continental margin immediately east of Sable Island, Nova Scotia, Canada (Kenchington et al., 2009, 2014b). The canyon supports an endangered population of northern bottlenose whales, Hyperoodon ampullatus (Forster 1770), which feed there at depths of 500-1500 m. They are thought

Corresponding author:

T.J. Kenchington

Email: gadus@istar.ca to eat primarily armhook squid, Gonatus spp. (Hooker et al., 2001, 2002), living at the whales' feeding depths, and one particular focus for the trawl surveys was the prey available to Gonatus spp. in The Gully. Hence, the surveys used an International Young Gadoid Pelagic Trawl ('IYGPT'), the meshes of which are too large for efficient sampling of Cyclothone spp. Those were the most abundant fish in the catches nonetheless. Limited additional sampling with a fine-mesh Tucker trawl took many C. microdon, plus a few Cyclothone pseudopallida Mukhacheva 1964 (Kenchington et al., 2014c), suggesting that most of the Cyclothone spp. in the canyon live and feed at the same depths to which the whales dive. Sampling limitations notwithstanding, we therefore examined the stomach contents of individuals in selected catches taken by the IYGPT for evidence of the prey available to the Cyclothone spp. at bathypelagic depths - and hence potentially at the base of the food chain supporting the whales. In the event, most of the Cyclothone spp. found with food in their stomachs had fed above $750 \mathrm{~m}$ depth and we therefore terminated the work.

We here present the results from those samples which were examined, as a confirmation of Mauchline \& Gordon's (1983) observations on C. microdon and a doubling of the limited available information on the diet of this extremely abundant species. To provide a context for the prey data, we first examine the spatio-temporal distribution of Cyclothone spp. in The Gully and outline the sizes, sexes and maturation stages of the specimens.

\section{MATERIALS AND METHODS}

\section{Study site}

The Gully is a focus for multidisciplinary studies of canyon ecology and much is now known (e.g. Greenan et al., 2014; 


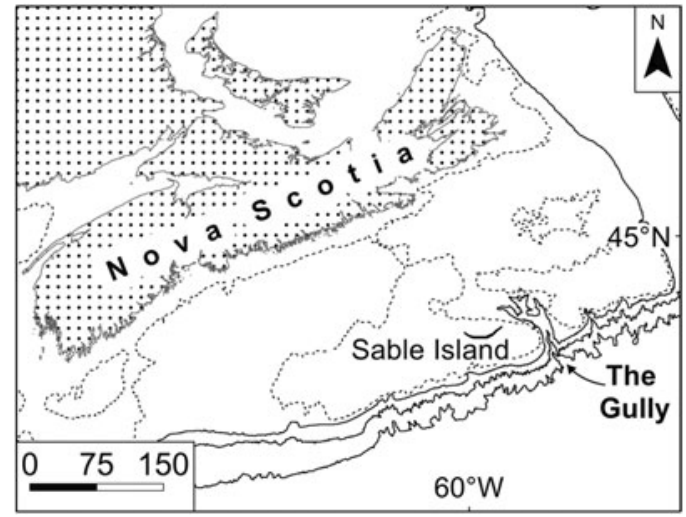

Fig. 1. Map of the Scotian Shelf, showing the location of The Gully. Contours shown at 100 (dashed), 200, 1000 and $2000 \mathrm{~m}$ depths. Scale bar in kilometres.

Kenchington et al., 2014a; MacIsaac et al., 2014; MoorsMurphy, 2014; Shan et al., 2014). Of present importance, within the depth range of Cyclothone spp., the canyon is flooded by either Labrador Sea Water or else North Atlantic Central Water (Kenchington et al., 2014c). Below rim depth, there is a slow net up-canyon flow, the water either upwelling over the rim or passing through a valley that links the canyon head to a mid-shelf basin (Greenan et al., 2014; Shan et al., 2014). Time-specific physical conditions during the trawl surveys have been presented by Kenchington et al. (2009, 2014c).

\section{Field methods}

Full details of the four surveys have been presented by Kenchington et al. $(2009,2014 \mathrm{~b})$. Three were in late summer (August-September 2007 to 2009) and one in early spring (March 2010). Each followed a depth-stratified, fixedstation, replicated design. Three principal stations (denoted 'Head', 'Main' and 'Deep') were established along the canyon thalweg (Figure 2). The depth strata were defined as $0-250,250-750,750-1250$ and $1250-1750 \mathrm{~m}$, though only the first two were available on the Head Station, while only the Deep Station could be fished to $1750 \mathrm{~m}$. By design, each survey usually made two (sometimes one or three) replicate standard IYGPT sets in each available stratum at each station in each of daylight and darkness. Depth control utilized a headline-mounted acoustic sensor while recording pressure sensors provided more accurate post hoc measurements of the maximum depth of each set. Limitations on ship time prevented the design from being fully achieved after 2007, though some additional trawling (not considered in the analyses presented here) was done at other stations and other depths.

The IYGPT is an open net, of $60 \mathrm{~m}^{2}$ mouth area, and necessarily fishes from the surface to the maximum depth of the set. In the Gully surveys, sets which fished below $250 \mathrm{~m}$ followed double-oblique ('V') profiles. After the 2007 survey, shooting and hauling were controlled to ensure that the net fished for $1 \mathrm{~h}$ in each stratum (except $30 \mathrm{~min}$ above $250 \mathrm{~m}$ ) down to the intended maximum depth. The catch taken by a particular set in its nominal stratum (its 'stratum catch') can thus be crudely estimated by subtracting the mean catch taken by sets which fished the next-shallower stratum (in the same survey, at the same station and during the same

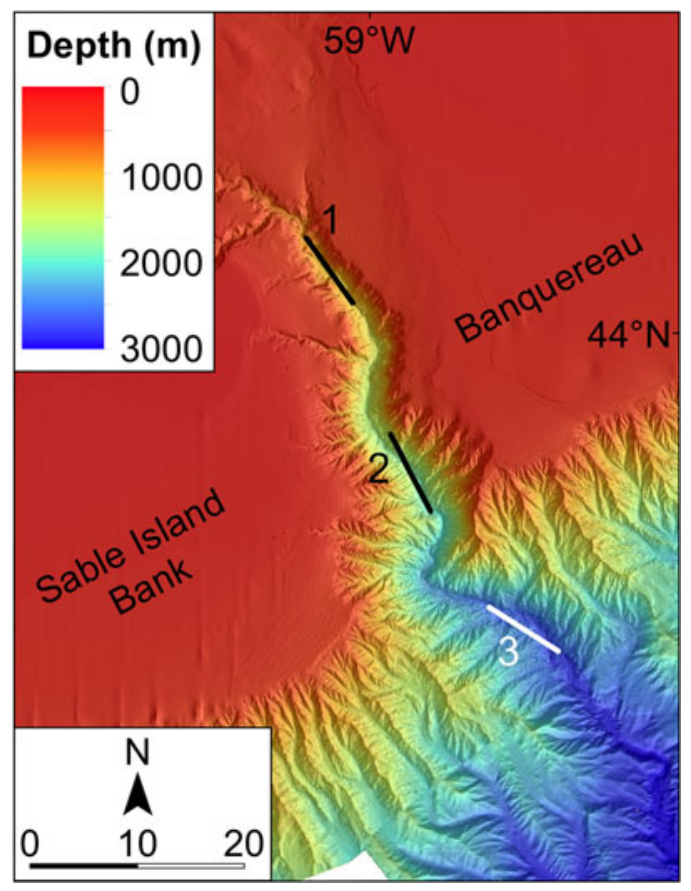

Fig. 2. Bathymetry of The Gully and the locations of the principal trawling stations: 1: Head Station, 2: Main Station, 3: Deep Station. Scale bar in kilometres. (High resolution bathymetric data are lacking for a small area near the southern limit of this map.)

diel phase) from the actual catch taken by the set in question. Such estimates cannot be precise but, with the fixed-station design of the Gully surveys and the high volumes of water filtered by the IYGPT, variability amongst the catches of replicate sets was generally low and such estimated stratum catches have proven informative (e.g. MacIsaac et al., 2014). In 2007, the net was dropped to and recovered from its nominal stratum as quickly as possible, somewhat reducing fishing time in shallower strata and hence depressing both the actual catches and the estimated stratum catches of sets that fished below $250 \mathrm{~m}$. No corrections for that difference were attempted. The sets confined to the $0-250 \mathrm{~m}$ stratum involved extra complications but took so few Cyclothone spp. that they are here only used qualitatively. Instead, the two shallowest strata are collapsed into a $0-750 \mathrm{~m}$ stratum, sampled by the sets that fished to $750 \mathrm{~m}$ depth.

The 2007 and 2008 surveys used standard IYGPT nets, which were then replaced by one constructed of knotless mesh. From 2008, the trawls were fitted with a rigid 'aquarium' codend. The combination of those advances resulted in less damage to the catch and hence a higher proportion of Cyclothone spp. specimens with their internal organs in place.

Being inadequately sampled by the IYGPT and very often badly damaged during capture, Cyclothone spp. were not an intended focus of the surveys. At sea, they were only sorted to genus and the catch weight recorded. Most were then discarded but a few catches from the early surveys were fixed in formalin and returned to shore. The latter became standard practice in 2010 .

\section{Analyses of spatio-temporal distribution}

Despite more than 100 standard sets being made on the three principal stations, replication remained too low to allow 
statistical analysis of the full four-factor survey design. Both the actual catches and the estimated stratum catches taken by each set were, therefore, averaged within each survey/ station/stratum/diel-period cell of the design (using arithmetic means) and then across those factors that showed no distributional pattern, the resulting matrices being examined for spatio-temporal patterns.

Within the constraints of available data, the statistical significances of three such observed patterns were checked by factorial ANOVA of log-transformed catch weights, with post hoc testing using Tukey's HSD, all calculated using JMP v.6.o.3 software (SAS Institute Inc., Cary, NC). A two-way test, with Station and Survey as factors, was applied to the actual catches taken by night sets that fished to $750 \mathrm{~m}$ on the Head Station, to $1250 \mathrm{~m}$ on the Main Station and to $1750 \mathrm{~m}$ on the Deep Station (representing depth-integrated biomasses across the full surveyed portion of the water column at each station) during the 2008-2010 surveys. A second test was applied to actual catches taken by $0-750 \mathrm{~m}$ sets on the Head Station and o-1250 m sets on the Main Station and on each of the four surveys, with Diel Phase, Station and Survey as the factors. Lastly, a three-way test of Station, Stratum and Survey was applied to the estimated stratum catches taken by night sets in the $0-750,750-1250$ and 1250-1750 m strata, on the Head, Main and Deep stations, during the 2008-2010 surveys. Throughout, the use of $\log$ transformations reduced non-normality and heteroscedasticity but residual data deficiencies and, especially, the testing only of hypotheses that appeared supported by the data will have tended to depress calculated probabilities. The limited amount of data will have had the reverse effect, while unequal numbers of replicates will have further distorted the results. Hence, the hypothesis tests may be indicative but were not definitive.

\section{Laboratory methods}

The Cyclothone spp. catches from 41 sets were returned to shore. Eighteen of those were selected for examination, in part haphazardly but also so as to include examples from various stations, depths, diel periods and both the 2007 and 2010 surveys. Samples of specimens were taken from each selected catch. The sampling fraction was chosen, in the form of a ratio $1: x$, to produce a sample of at least 20 fish. Specimens were then extracted haphazardly from the preserved material, every $x^{\text {th }}$ individual being processed.

The specimens taken for processing were identified to species, to the extent possible, following Badcock's (1984) key, and their standard lengths were measured to the nearest millimetre. If the stomach was present, it was opened and the lumen examined, the content being recorded as either empty or containing prey - the latter being extracted and retained for further examination. If gonad tissue was present, the sex of the individual was determined, as was, for adult females only, the developmental stage of the ovaries. Both sexing and staging followed Badcock \& Merrett (1976), in so far as their scheme could be applied without histological preparations.

The retained stomach contents were initially screened, removing those which contained only unidentifiable material. The remainder were examined (by J.M. Spry, SpryTech Biological Services Inc., Elmsdale, Nova Scotia) and identified in as much detail as their condition allowed.

\section{RESULTS}

\section{Spatio-temporal distribution}

Cyclothone spp. were found by each survey, on every station, and in the catches of sets made in each nominal stratum, though not those of every set that fished exclusively above $250 \mathrm{~m}$ depth. The catches barely differed between daylight and night. There were gaps in the data from the Deep Station but the depth distribution of catches taken on the Main Station gave no indication of diel migrations (Table 1).

The depth-integrated biomass of Cyclothone spp., excluding any fish below the deepest stratum at each station, showed only a weak trend along the canyon. The mean catch by sets which reached $1750 \mathrm{~m}$ depth on the Deep Station was $273 \mathrm{~g}$, compared with $232 \mathrm{~g}$ taken by sets made to $1250 \mathrm{~m}$ on the Main Station and $238 \mathrm{~g}$ by $750 \mathrm{~m}$ sets on the Head Station. To avoid empty cells, formal testing of that trend was confined to night sets during the latter three surveys. Two-way ANOVA of those catches showed a nonsignificant Station $\times$ Survey interaction term and, after its elimination, a significant Station effect $\left(F_{(2,9)}=11.566, P=\right.$ 0.003). Post hoc tests found no significant difference between the Head and Main stations but the Deep Station stood out for its higher catches.

Full arrays of daylight and night catch data from all four surveys, suited to statistical examination of inter-annual trends, are only available for $0-750 \mathrm{~m}$ sets on the Head and Main stations and $0-1250 \mathrm{~m}$ sets on the Main Station alone. For the Deep Station, near-complete coverage of both $0-750$ and $0-1250 \mathrm{~m}$ sets is available. Four of those five station/depth-range series show 2007 catches averaging higher than those taken in 2008 or 2009 (Table 2) - the reverse trend to that expected from the inter-annual differences in field survey methods. The spring 2010 catches were

Table 1. Arithmetic mean estimated stratum catch of Cyclothone spp. (in grams) at each of the three stations along the canyon thalweg, with confidence intervals of one standard deviation.

\begin{tabular}{|c|c|c|c|c|c|c|}
\hline \multirow{2}{*}{$\begin{array}{l}\text { Station } \\
\text { Diel period } \\
\text { Stratum }\end{array}$} & \multicolumn{2}{|l|}{ Head } & \multicolumn{2}{|l|}{ Main } & \multicolumn{2}{|l|}{ Deep } \\
\hline & Day & Night & Day & Night & Day & Night \\
\hline $0-750 \mathrm{~m}$ & $274 \pm 212$ & $184 \pm 80$ & $49 \pm 36$ & $52 \pm 42$ & $74 \pm 40$ & $59 \pm 38$ \\
\hline $750-1250 \mathrm{~m}$ & & & $161 \pm 114$ & $200 \pm 172$ & $103 \pm 92$ & $33 \pm 41$ \\
\hline $1250-1750 \mathrm{~m}$ & & & & & & $195 \pm 93$ \\
\hline
\end{tabular}

(For the sub-surface strata, each estimated stratum catch is the actual catch taken by a set, less the average of the catches taken by sets nominally made in the next-shallower stratum during the same survey, the same diel period and on the same station). 
Table 2. Arithmetic mean catches of Cyclothone spp. (in grams), with confidence intervals of one standard deviation, for each survey and each of the station/depth-range combinations for which data are available for near-complete coverage of the survey design.

\begin{tabular}{llcrrr}
\hline Station & $\begin{array}{l}\text { Survey } \\
\text { Depths fished }\end{array}$ & 2007 & 2008 & 2009 & 2010 \\
\hline Head & $0-750 \mathrm{~m}$ & $340 \pm 254$ & $227 \pm 134$ & $206 \pm 16$ & $90 \pm 21$ \\
Main & $0-750 \mathrm{~m}$ & $82 \pm 53$ & $43 \pm 15$ & $39 \pm 18$ & $26 \pm 10$ \\
Main & $0-1250 \mathrm{~m}$ & $361 \pm 221$ & $151 \pm 61$ & $242 \pm 44$ & $143 \pm 18$ \\
Deep & $0-750 \mathrm{~m}$ & $99 \pm 51$ & $58 \pm 14$ & $29 \pm 9$ & $54 \pm 30$ \\
Deep & $0-1250 \mathrm{~m}$ & $123 \pm 28$ & $153 \pm 98$ & $116 \pm 54$ & $85 \pm 57$ \\
\hline
\end{tabular}

generally lower than those taken during the summer. The inter-annual differences on the Head and Main stations were, however, only marginally significant $\left(F_{(3,22)}=3.422\right.$, $P=0.035$ ), after removal of non-significant interaction terms, while post hoc testing indicated that the only significant difference was between the 2007 and the 2010 catches. If a Bonferroni correction were applied, in response to the selection of hypotheses to test, based on apparent trends, that result would be judged non-significant.

The depth distribution of Cyclothone spp. catches did vary along the canyon. On the Deep Station, the fish were primarily bathypelagic but substantial catches were taken above $750 \mathrm{~m}$ depth on the Head Station (Table 1). The estimated stratum catches taken by night sets during the latter three surveys showed a significant Station $\times$ Stratum interaction $\left(F_{(1,15)}=\right.$ 13.808, $P=0.002$ ), indicative of the shallower distribution of the fish further up the canyon. That trend might be less pronounced than it appears if other Cyclothone spp. were concentrated between the seabed and the deepest stratum on the Main and Head stations but the very limited trawling undertaken in those near-bottom layers did not take large amounts of Cyclothone spp.

Of 43 sets that did not pass $250 \mathrm{~m}$ depth, 15 had no recorded catch of Cyclothone spp., while the average catch by such shallow sets on the Main and Deep stations was $5 \mathrm{~g}$, suggesting minor contamination carried over from previous, deeper trawling. However, the 12 shallow sets made on the Head Station took an average of $22.8 \mathrm{~g}$, one catching $108 \mathrm{~g}$. While that set was immediately preceded by a large catch taken at greater depth, one each on the Head and Deep stations took 26 and $25 \mathrm{~g}$ of Cyclothone spp. respectively, despite each following some hours with no trawling. The measured maximum headline depths of those sets were 261 and $273 \mathrm{~m}$, while their footropes reached 4-6 m deeper (Kenchington et al., 2009). Moreover, the stomachs of four individual Cyclothone microdon extracted from the catches of $250 \mathrm{~m}$ night sets (two on the Head Station and one on the Main: maximum headline depth $264 \mathrm{~m}$ ) were found to contain incompletely digested prey material. Thus, in the canyon and especially near its head, the depth range of the genus extends very nearly to, and probably above, $250 \mathrm{~m}$ depth.

\section{Specimens examined}

A total of 736 Cyclothone individuals taken by 18 sets were examined, the entire catches of those sets totalling more than 6100 fish of the genus. 354 of the examined individuals were identified as Cyclothone microdon and four as Cyclothone pseudopallida, while 125 were one or the other of those species. The remaining specimens were too damaged for specific identification but none had any observable characteristics diagnostic of other species.

Sex could be determined for 310 of the specimens, of which 259 were female (the great majority being in Stage VI, with ripe eggs), while the remainder included males, immatures and hermaphrodites - C. microdon being a protandrous hermaphrodite (Badcock, 1986). Examination of the specimens indicated that the preponderance of specimens recorded as ripe females resulted primarily from that sex and stage being more readily recognized amongst the often-damaged material.

Standard length (after fixation) could be measured for 662 specimens. Following expansion by the inverse of the sampling fractions for each set, those measurements showed a length frequency (Figure 3) with modes at 32 and $53 \mathrm{~mm}$ (average $42.0 \mathrm{~mm}$ ). The larger mode was primarily composed of females, which also comprised nearly a third of the $32 \mathrm{~mm}$ mode, most of which was male. The lengths of the four confirmed C. pseudopallida averaged slightly less than the rest of the collection, at $27,28,33$ and $46 \mathrm{~mm}$ respectively. The available length data were mostly from fish taken in 2010. The summer 2007 length frequency tended towards smaller fish, with a mode at $38 \mathrm{~mm}$ and few individuals larger than $50 \mathrm{~mm}$.

\section{Stomach contents}

Of the examined specimens, 490 had surviving stomachs, $82 \%$ of which were empty. No diel cycle was apparent in that proportion. The 89 non-empty stomachs included at least one specimen from each of 16 of the selected sets. Nine sets

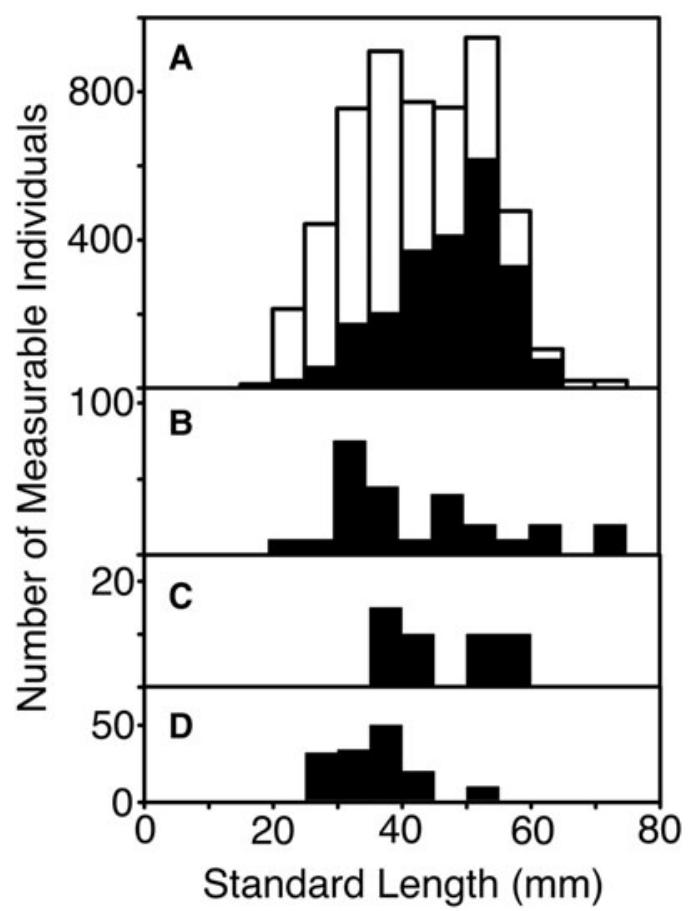

Fig. 3. Length frequency of measurable Cyclothone spp. caught by the sets selected for examination of samples (standard lengths in millimetres, grouped in $5 \mathrm{~mm}$ increments). Numbers of fish are expanded by inverse of sampling ratio applied to the catch from each set. (A) All specimens (white) and confirmed females (black), (B) confirmed males, (C) confirmed hermaphrodites, (D) confirmed immature specimens. 
each yielded more than $20 \%$ non-empty stomachs. Those nine were spread across all three stations, both daylight and night fishing and both the 2007 and 2010 surveys. In the catches taken by sets made to $750 \mathrm{~m}$ depth, the proportion of nonempty stomachs declined up the canyon, from $36 \%$ on the Deep Station through $25 \%$ on the Main Station to $17 \%$ on the Head Station. Sets that did not fish below $250 \mathrm{~m}$ depth had non-empty proportions (mean: 20.3\%, maximum: $33.3 \%$ ) almost identical to those of sets that reached $750 \mathrm{~m}$ (mean: $23.1 \%$, maximum 34.5\%). In contrast, the sets which reached $1750 \mathrm{~m}$ depth on the Deep Station produced a lower non-empty proportion (mean: $11.6 \%$, maximum $21.1 \%)$, despite fishing through shallower depths. If both the catches and the proportions of individuals with non-empty stomachs that were taken by those $1750 \mathrm{~m}$ sets while they fished above $750 \mathrm{~m}$ depth were assumed equal to the catches and non-empty proportions taken by sets that went no deeper than $750 \mathrm{~m}$, then the proportion of non-empty stomachs in individuals taken between 750 and $1750 \mathrm{~m}$ could be crudely estimated. For the Cyclothone spp. on the Deep Station in 2010, that estimate is $8.3 \%$.

The 89 fish with non-empty stomachs included 38 confirmed females (some with ripe eggs and one spent), one hermaphrodite, two immatures and eight males. The proportion of males was higher, and that of females lower, than amongst the individuals with empty stomachs but not significantly so. Amongst the females, there was no apparent difference in the proportions of the various maturity stages between those with empty or non-empty stomachs. The standard lengths of the 89 individuals in the latter group lay in the range $24-59 \mathrm{~mm}$, with a mean of $41.2 \mathrm{~mm}$. Two of the four identified C. pseudopallida were among the individuals with non-empty stomachs, though one contained no identifiable prey material. Another 63 individuals with non-empty stomachs were confirmed as C. microdon, 32 of which had identifiable prey items amongst their stomach contents.
Those were among the 42 specimens which contained identifiable prey. The numbers of non-empty stomachs with and without identifiable prey were generally approximately equal across depths and stations. Every identifiable prey item in the 42 stomachs was derived from a small crustacean (Table 3). Three stomachs contained parts of at least four amphipods. Eleven ostracods of the subfamily Conchoeciinae were found in 10 stomachs (one being that of a C. pseudopallida). Otherwise, all prey identifiable below subphylum were copepods and all identifiable to order were calanoids. Those included members of six families and seven genera. No particular genus was especially prominent, five being represented by four to six prey items each. Only a few of the copepod pieces could be identified to species. Those that could be comprised individuals of Metridia lucens Boeck, 1865, Paraeuchaeta norvegica (Boeck 1872) and Pleuromamma gracilis Claus, 1863 . One prey item was probably Calanus finmarchicus (Gunnerus 1770), while both of the recorded Euchirella spp. were probably Euchirella rostrata (Claus 1866).

The observed stomach contents of the 42 Cyclothone spp. may have comprised as few as 56 prey individuals. One small $(25 \mathrm{~mm})$ mature female, taken above $250 \mathrm{~m}$ depth on the Main Station, had two Calanus spp., three probable Pseudocalanus spp., one Paraeuchaeta sp., four unidentifiable digested copepod fragments and parts of two Themisto spp. in her stomach. Three other fish each contained the remains of one copepod and one or two ostracods. Two fish had each eaten two copepods. The remaining 36 Cyclothone spp. individuals may have ingested only a single prey item each.

\section{DISCUSSIDN}

Few Cyclothone spp. from the continental margin off Nova Scotia have been identified to species but it was clear before

Table 3. Prey taxa found in stomachs of Cyclothone spp., showing the number of stomachs that contained each taxon and the minimum number of ingested individuals necessary to explain the observed pieces of prey.

\begin{tabular}{|c|c|c|c|c|c|c|c|}
\hline \multicolumn{6}{|l|}{ Prey taxon } & \multirow{2}{*}{$\begin{array}{l}\text { Number of stomachs } \\
\text { containing taxon }\end{array}$} & \multirow{2}{*}{$\begin{array}{l}\text { Minimum number } \\
\text { of individuals }\end{array}$} \\
\hline Subphylum & Class or subclass & Order & Family or subfamily & Genus & Species & & \\
\hline \multirow[t]{17}{*}{ Crustacea } & \multirow{5}{*}{ Copepoda } & \multirow{5}{*}{ Calanoida } & & & & 42 & 56 \\
\hline & & & & & & 30 & 38 \\
\hline & & & & & & 27 & 34 \\
\hline & & & Aetideidae & & & 3 & 3 \\
\hline & & & & Euchirella & & 2 & 2 \\
\hline & \multirow[t]{9}{*}{1} & & Calanidae & Calanus & & 4 & 5 \\
\hline & & & Clausocalanidae & Pseudocalanus & & 2 & 4 \\
\hline & & & Euchaetidae & Paraeuchaeta & & 6 & 6 \\
\hline & & & & & P. norvegica & 2 & 2 \\
\hline & & & Metridinidae & & & 10 & 10 \\
\hline & & & & Metridia & M. lucens & 6 & 6 \\
\hline & & & & Pleuromamma & & 4 & 4 \\
\hline & & & & & P. gracilis & 3 & 3 \\
\hline & & & Scolecitrichidae & Scaphocalanus & & 1 & 1 \\
\hline & \multirow[t]{2}{*}{ Malacostraca } & Amphipoda & & & & 3 & 4 \\
\hline & & & Hyperiidae & Themisto & & 1 & 2 \\
\hline & Ostracoda & Halocypridina & Conchoeciinae & & & 10 & 11 \\
\hline
\end{tabular}

Counts presented for higher taxa include those shown for lower constituent taxa. Prey items are here listed under the lowest taxon to which they were identified, even if that identification was uncertain. However, every taxon named here was definitively identified from at least one piece extracted from a stomach. 
the Gully surveys that Cyclothone microdon is the principal member of the genus there (McKelvie \& Haedrich, 1985; Scott \& Scott, 1988). Small numbers of Cyclothone pseudopallida have also been reported (e.g. Scott \& Scott, 1988). A range of sizes and both sexes of C. microdon are present in the canyon, some females being in spawning condition. In the eastern North Atlantic, sex reversal seems universal in $C$. microdon, length ranges of juveniles and adult females showing little overlap, while the largest individuals are all female (Badcock \& Merrett, 1976; Badcock, 1986; McKelvie, 1989). Hence, the difference in modal sizes of the sexes in The Gully, along with the presence of some hermaphrodites, were expected. However, in the present study female and juvenile length ranges overlapped broadly, while the largest individual examined was male. No less remarkable was the change in size composition between summer 2007 and spring 2010, suggestive of a recruitment event followed by growth of the abundant year-class.

On the Deep Station, Cyclothone spp. were mostly distributed across the deeper-mesopelagic and upper bathypelagic zones, as expected for C. microdon (Badcock, 1984), but they were found at lesser depths further up the canyon, such that they were mesopelagic fish on the Head Station, with some caught near or above $250 \mathrm{~m}$. That is within the expected depth range for C. pseudopallida but remarkably shallow for C. microdon - and three individuals caught by shallow sets were confirmed as that species. Elevation of biological and physical features towards a canyon head is not unusual but the extent of this trend in the vertical distribution of Cyclothone spp. was exceptional. Being small and weakbodied, Cyclothone spp. appear as much planktonic as nektonic. They are also oceanic and perhaps poorly adapted to life in a canyon. Certainly, their distribution in The Gully is consistent with their being passively carried up-canyon and then upwards by the known water flow (Greenan et al., 2014; Shan et al., 2014), until increasing light levels discourage further ascent, while their abundance is thinned by predation.

The greater biomass observed in summer 2007, relative to that in the following summers, was at best marginally significant but a parallel trend has been noted in the highly abundant krill, Meganyctiphanes norvegica Holt \& Tattersall, 1905, taken by the same surveys (MacIsaac et al., 2014). Both may have been consequences of the unusual oceanographic conditions that year (Kenchington et al., 2009). The relative depression in the depth distribution of Cyclothone on the Deep Station during the 2009 survey was probably related to the presence of Warm Slope Water: the shelf/slope front which delimits that water mass usually lies much further south but cut across the Station during that one survey (Kenchington et al., 2014C).

With their weak bodies, lack of diel migratory behaviour and an absence of the bioluminescent lures seen in many bathypelagic fishes, Cyclothone spp. appear adapted for minimizing energy use and relying on chance encounters with prey, which necessarily limits their consumption rates and energy intake (Maynard, 1982). The $82 \%$ empty stomachs observed in The Gully, along with the very low numbers of stomachs containing more than a single prey item, are typical for the genus (e.g. Collard, 1970; De Witt \& Cailliett, 1972; Gorelova \& Tseytlin, 1979; Gorelova, 1980, Maynard, 1982; Mauchline \& Gordon, 1983; Roe \& Badcock, 1984; Gordon et al., 1985; Palma, 1990; Burghart et al., 2010; McClain-Counts, 2010). Cyclothone microdon above $750 \mathrm{~m}$ depth on the Deep Station do seem to have enjoyed better feeding opportunities, with only $64 \%$ of stomachs empty. That figure rose to $75 \%$ inside the canyon mouth and $83 \%$ at the Head Station, at least in March 2010, suggesting lowered prey availability further up The Gully.

Use of stomach contents as an indicator of diets, especially in a species that has a low proportion of stomachs containing identifiable prey, necessarily requires an assumption that the fish do not consume substantial amounts of soft-bodied animals which leave little trace in their stomachs. Within that limitation, previous studies of the diets of Cyclothone spp. have found them to be dominated by small crustaceans, especially calanoid copepods (De Witt \& Cailliett, 1972; Gorelova, 1980; Maynard, 1982; Mauchline \& Gordon, 1983; Roe \& Badcock, 1984; Gordon et al., 1985; Palma, 1990; Yoon et al., 2007), as was seen in The Gully. Off Hawaii, Maynard (1982) found some evidence of selection of preferred prey types but it seems that differences in recorded Cyclothone spp. diets owe more to variations in prey availability than anything else. Thus, the relatively high proportion of continentalshelf species in the stomachs of fish in The Gully is unsurprising. Pleuromamma spp., diel migrants to mesopelagic depths and hence species of the continental margins and open ocean, have frequently been reported as principal constituents of the diets of Cyclothone spp. (e.g. Gorelova, 1980; Maynard, 1982; Mauchline \& Gordon, 1983; Roe \& Badcock, 1984; Gordon et al., 1985; Palma, 1990; Hopkins et al., 1996; Burghart, 2006; Yoon et al., 2007; McClain-Counts, 2010). They were only recorded in four of the stomachs from The Gully.

The depth distributions of copepods in The Gully may be as atypical for their respective species as is that of $C$. microdon and, if so, must remain unknown in the absence of site-specific data. However, the expected distributions of each of the

Table 4. Depth distributions of copepod taxa found in the stomachs of Cyclothone spp.

\begin{tabular}{lll}
\hline Prey taxon & Principal depth zone & Sources \\
\hline $\begin{array}{l}\text { Calanus finmarchicus } \\
\text { Euchirella spp. }\end{array}$ & $\begin{array}{l}\text { Overwinter in mesopelagic } \\
\text { Mesopelagic in daylight }\end{array}$ & Head \& Pepin (2008) \\
Metridia lucens & Roe (1984); Pancucci-Papadopoulou et al. (1992); & Andersen et al. (2001) \\
& summer: females epipelagic,males in lower mesopelagic & Gislason (2008) \\
Paraeuchaeta norvegica & Overwinters 6oo- 1600 m & Gislason (2008) \\
Pleuromamma spp. & Diel migrants, mesopelagic in daylight & Roe (1972); Buskey et al. (1989); Gislason (2008) \\
Pseudocalanus spp. & Overwinter below 50o m & Corkett \& McLaren (1978); Richter (1995) \\
Scaphocalanus spp. & Lower mesopelagicCan be epipelagic at night & Roe (1972); Deevey \& Brooks (1977) \\
\hline
\end{tabular}


identified prey types eaten by Cyclothone spp. in the canyon would have made them available to the fish between depths of 250 and $750 \mathrm{~m}$, where most of the Cyclothone spp. with non-empty stomachs appear to have been caught. The depth distributions of the copepods are summarized in Table 4. The amphipods in stomachs from The Gully could not be identified to species but the Themisto spp. taken by the IYGPT were primarily Themisto compressa Goës 1865, with a small admixture of Themisto libellula (Lichtenstein in Mandt 1822). Themisto abyssorum Boeck 1870 may also have been present but not retained by the large meshes of the trawl (MacIsaac, 2011). Themisto compressa is primarily epipelagic but has been taken along the North American continental margin at bathypelagic depths (to a maximum of more than $1400 \mathrm{~m}$ : Bowman et al., 1982). The depth ranges of the Conchoeciinae have been little studied. Bashmanov \& Chavtur (2008) have recently summarized the available information on Boroecia borealis (Sars 1866) in the North Atlantic, finding that species most abundant around $500 \mathrm{~m}$ depth in waters north of $45^{\circ} \mathrm{N}$, while the known depth range along the North American continental margin is $75-1500 \mathrm{~m}$. In the north-east Atlantic, Angel $(1977,1984)$ found a variety of species in the subfamily to be most abundant at depths of some hundreds of metres.

In summary, the diet of $C$. microdon in The Gully is consistent with Mauchline \& Gordon's (1983) observations of the species in the Rockall Trough. Both differ only in detail from the diets previously described for the mesopelagic species in the genus. The bulk of their prey comprises calanoid copepods which have themselves fed in the epipelagic layer and then migrated down, either seasonally or at dawn. In essence, instead of swimming up to feed on the herbivores near the surface, as the myctophids do, these most abundant of fishes remain at depth and wait for the copepods to descend - though the deep diel migrants are only a small fraction of all surface-feeding calanoids, limiting the prey supply for non-migratory fish.

\section{ACKNDWLEDGEMENTS}

This study could not have been undertaken without the exceptional efforts of the captains, crews and scientific staffs of the four survey cruises made in The Gully. It was no less dependent on the expertise and identifications of Jacquelyn Spry, SpryTech Biological Services Inc. We are further indebted to Kevin MacIsaac and Megan Best who, in addition to their work at sea, provided essential support in the laboratory ashore, to Cam Lirette for figure drafting and especially to Ellen Kenchington, who coordinated our efforts, obtained necessary funding, performed the ANOVAs and provided valuable comment on earlier drafts.

\section{FINANCIAL SUPPDRT}

The authors undertook the work reported here as unfunded volunteers at the Bedford Institute of Oceanography. The overall program of research into the pelagic ecosystems of The Gully, including the four field surveys, was undertaken by the Department of Fisheries and Oceans, with support from the Government of Canada's 'Health of the Oceans' initiative.

\section{REFERENCES}

Andersen V., Gubanova A., Nival P. and Ruellet T. (2001) Zooplankton community during the transition from spring bloom to oligotrophy in the open NW Mediterranean and effects of wind events. 2. Vertical distributions and migrations. Journal of Plankton Research 23, $243-261$.

Angel M.V. (1977) Studies on Atlantic halocyprid ostracods: vertical distributions of the species in the top $1000 \mathrm{~m}$ in the vicinity of $44^{\circ} \mathrm{N}, 13^{\circ} \mathrm{W}$. Journal of the Marine Biological Association of the United Kingdom 57, 239-252.

Angel M.V. (1984) The diel migrations and distributions within a mesopelagic community in the North East Atlantic. 3. Planktonic ostracods, a stable component in the community. Progress in Oceanography 13, $319-351$.

Badcock J. (1984) Gonostomatidae. In Whitehead P.J.P., Bauchot M.-L., Hureau J.-C., Nielsen J. and Tortonese E. (eds) Fishes of the north-eastern Atlantic and the Mediterranean I. Paris: UNESCO, pp. 284-301.

Badcock J. (1986) Aspects of the reproductive biology of Gonostoma bathyphilum (Gonostomatidae). Journal of Fish Biology 29, 589-603.

Badcock J. and Merrett N.R. (1976) Midwater fishes in the eastern North Atlantic - I. Vertical distribution and associated biology in $30^{\circ} \mathrm{N}$, $23^{\circ} \mathrm{W}$, with developmental notes on certain myctophids. Progress in Oceanography 7, 3-58.

Bashmanov A.G. and Chavtur V.G. (2008) Distribution of Boroecia borealis (Ostracoda: Halocyprididae) in the Arctic Ocean and adjacent waters of the Atlantic. Russian Journal of Marine Biology 34, 341-350.

Bowman T.E., Cohen A.C. and McManus McGuiness M. (1982) Vertical distribution of Themisto gaudichaudii (Amphipoda: Hyperiidea) in Deepwater Dumpsite 106 off the mouth of Delaware Bay. Smithsonian Contributions to Zoology $24 \mathrm{pp}$.

Burghart S.E. (2006) Micronektonic community composition and trophic structure within the bathypelagic zone in the eastern Gulf of Mexico. PhD thesis. University of South Florida, Tampa, FL, USA.

Burghart S.E., Hopkins T.L. and Torres J.J. (2010) Partitioning of food resources in bathypelagic micronekton in the eastern Gulf of Mexico. Marine Ecology Progress Series 399, 131-140.

Buskey E.J., Baker K.S., Smith R.C. and Swift E. (1989) Photosensitivity of the oceanic copepods Pleuromamma gracilis and Pleuromamma xiphias and its relationship to light penetration and daytime depth distribution. Marine Ecology Progress Series 55, 207-216.

Collard S.B. (1970) Forage of some eastern Pacific midwater fishes. Copeia 1970, 348-354.

Corkett C.J. and McLaren I.A. (1978) The biology of Pseudocalanus. Advances in Marine Biology 15, 1-231.

De Witt F.A. and Cailliett G.M. (1972) Feeding habits of two bristlemouth fishes, Cyclothone acclinidens and C. signata. Copeia 1972, $868-871$.

Deevey G.B. and Brooks A.L. (1977) Copepods of the Sargasso Sea off Bermuda: species composition, and vertical and seasonal distribution between the surface and $2000 \mathrm{~m}$. Bulletin of Marine Science 27, 256-291.

Gislason A. (2008) Vertical distribution and seasonal dynamics of mesozooplankton in the Iceland Basin. Marine Biology Research 4, $401-413$.

Gordon J.D.M., Nishida S. and Nemoto T. (1985) The diet of mesopelagic fish from the Pacific coast of Hokkaido, Japan. Journal of the Oceanographic Society of Japan 41, 89-97. 
Gorelova T.A. (1980) Feeding of deep-sea fish of the genus Cyclothone (Gonostomatidae, Pisces). Oceanology 20, 209-214.

Gorelova T.A. and Tseytlin V.B. (1979) Feeding of mesopelagic fish of the genus Cyclothone. Oceanology 19, 736-739.

Greenan B.J.W., Petrie B.D. and Cardoso D.A. (2014) Mean circulation and high-frequency flow amplification in the Sable Gully. Deep Sea Research II 104, 20-34.

Head E. and Pepin P. (2008) Variations in overwintering depth distributions of Calanus finmarchicus in the slope waters of the NW Atlantic continental shelf and the Labrador Sea. Journal of Northwest Atlantic Fisheries Science 39, 49-69.

Hooker S.K., Iverson S.J., Ostrom P. and Smith S.C. (2001) Diet of northern bottlenose whales inferred from fatty-acid and stable-isotope analyses of biopsy samples. Canadian Journal of Zoology 79, 14421454 .

Hooker S.K., Whitehead H., Gowans S. and Baird R.W. (2002) Fluctuations in distribution and patterns of individual range use of northern bottlenose whales. Marine Ecology Progress Series 225, 287-297.

Hopkins T.L., Sutton T.T. and Lancraft T.M. (1996) The trophic structure and predation impact of a low latitude midwater fish assemblage. Progress in Oceanography 38, 205-239.

Kenchington E.L., Cogswell A.T., MacIsaac K.G., Beazley L., Law B.A. and Kenchington T.J. (2014a) Limited depth zonation among bathya epibenthic megafauna of The Gully submarine canyon, northwest Atlantic. Deep-Sea Research Part II 104, 67-82.

Kenchington T.J., Benjamin R., Best M., Cogswell A., Cook A., DeVaney S., Lirette C., MacDonald B., MacIsaac K., Mallam P., McIntyre T., McMillan A., Moors-Murphy H., Morton G., Paon L., Roach S., Shea E., Themelis D. and Kenchington E.L.R (2014b) Field methods of the 2008, 2009 and 2010 surveys of mesoand bathypelagic micronekton in The Gully. Canadian Technical Report of Fisheries and Aquatic Sciences, no. 3076, 73 pp.

Kenchington T.J., Best M., Bourbonnais-Boyce C., Clement P., Cogswell A., MacDonald B., MacEachern W.J., MacIsaac K., MacNab P., Paon L., Reid J., Roach S., Shea E., Themelis D. and Kenchington E.L.R. (2009) Methodology of the 2007 survey of meso- and bathypelagic micronekton of the Sable Gully: Cruise TEM768. Canadian Technical Report of Fisheries and Aquatic Sciences, no. 2853, 91 pp.

Kenchington T.J., Cochrane N.A., Gjerdrum C., Greenan B.J.W., Lirette C., Moors-Murphy H. and Thompson S.E. (2014c) The environmental background to the 2008, 2009 and 2010 meso- and bathypelagic trawl surveys of The Gully. Canadian Technical Report of Fisheries and Aquatic Sciences, no. 3114, 251 pp.

MacIsaac K.G. (2011) The larger pelagic crustacea of The Gully submarine canyon. MSc thesis, Dalhousie University, Halifax, Canada.

MacIsaac K.G., Kenchington T.J., Kenchington E.L.R. and Best M. (2014) The summer assemblage of large pelagic crustacea in The Gully submarine canyon: major patterns. Deep-Sea Research Part II $104,51-66$

Marshall N.B. (1954) Aspects of deep-sea biology. London: Hutchinson.

Mauchline J. and Gordon J.D.M. (1983) Diets of clupeoid, stomiatoid and salmonid fish of the Rockall Trough, northeastern Atlantic Ocean. Marine Biology 77, 67-78.

Maynard S.D. (1982) Aspects of the biology of mesopelagic fishes of the genus Cyclothone (Pisces: Gonostomatidae) in Hawaiian waters. $\mathrm{PhD}$ thesis, University of Hawaii, Manoa, Hawaii, USA.
McClain-Counts J.P. (2010) Trophic structure of midwater fishes over cold seeps in the north central Gulf of Mexico. $\mathrm{PhD}$ thesis, University of North Carolina Wilmington, Wilmington, NC, USA.

McKelvie D.S. (1989) Latitudinal variation in aspects of the biology of Cyclothone braueri and C. microdon (Pisces: Gonostomatidae) in the eastern North Atlantic Ocean. Marine Biology 102, 413-424.

McKelvie D.S. and Haedrich R.L. (1985) Mesopelagic fishes (excluding Myctophidae) from research surveys off Newfoundland and Labrador. NAFO Scientific Council Studies 8, 67-75.

Moors-Murphy H.B. (2014) Submarine canyons as important habitat for cetaceans, with special reference to The Gully: a review. Deep-Sea Research Part II 104, 6-19.

Palma S. (1990) Ecologie alimentaire de Cyclothone braueri Jesperson et Taning, 1926 (Gonostomatidae) en mer Ligure, Méditerranée occidentale. Journal of Plankton Research 12, 519-534.

Pancucci-Papadopoulou M.-A., Siokoufrangou I., Theocharis A. and Georgopoulos D. (1992) Zooplankton vertical distribution in relation to the hydrology in the NW Levantine and the SE Aegean seas (spring 1986). Oceanologica Acta 15, 365-381.

Richter C. (1995) Seasonal changes in the vertical distribution of mesozooplankton in the Greenland Sea Gyre $\left(75^{\circ} \mathrm{N}\right)$ : distribution strategies of calanoid copepods. ICES Journal of Marine Science 52, 533-539.

Roe H.S.J. (1972) The vertical distributions and diurnal migrations of calanoid copepods collected on the Sond cruise, 1965. III. Systematic account: families Euchaetidae up to and including the Metridiidae. Journal of the Marine Biological Association of the United Kingdom $52,525-552$.

Roe H.S.J. (1984) The diel migrations and distributions within a mesopelagic community in the north east Atlantic. 4. The copepods. Progress in Oceanography 13, 353-388.

Roe H.S.J. and Badcock J. (1984) The diel migrations and distributions within a mesopelagic community in the north east Atlantic. 5. Vertical migrations and feeding of fish. Progress in Oceanography 13 , $389-424$.

Scott W.B. and Scott M.G. (1988) Atlantic fishes of Canada. Toronto: University of Toronto Press. [Canadian Bulletin of Fisheries and Aquatic Sciences, no. 219.]

Shan S., Sheng J. and Greenan B.J.W. (2014) Modelling study of threedimensional circulation and particle movement over the Sable Gully of Nova Scotia. Ocean Dynamics 64, 117-142.

and

Yoon W.D., Nival P., Choe S.M., Picheral M. and Gorsky G. (2007) Vertical distribution and nutritional behaviour of Cyclothone braueri, Nematoscelis megalops, Meganyctiphanes norvegica and Salpa fusiformis in the NW Mediterranean mesopelagic zone. International Council for the Exploration of the Sea (CM Papers and Reports), CM 2007/F:03, 28 pp.

\section{Correspondence should be addressed to:}

T.J. Kenchington

Department of Fisheries \& Oceans, Maritimes Region, Ocean Ecosystem Sciences Division, Bedford Institute of Oceanography, PO Box 1006, Dartmouth, Nova Scotia B2Y 4A2, Canada email: gadus@istar.ca 